\title{
Avian Cholera in the Eastern Canadian Arctic: Investigating Disease Origins and Reservoirs
}

\section{by $N$. Jane Harms}

It is safe to predict that disease in its many manifestations will become even more significant for wild animals in the future and that there will be increasing pressure on wildlife biologists to "manage" disease.

Wobeser (2006:6)

\section{INTRODUCTION}

I N THE PAST, DISEASES IN WILDLIFE SPECIES have often been considered important only when they threaten the health of domestic species or humans (Daszak et al., 2000). More recently, with globalization, ecosystems increasingly altered by humans, and climatic anomalies, the world is undergoing rapid and often striking ecological change, which can have a marked effect on various assemblages of complex host-parasite relationships (Epstein, 2002). In this context, newly emerging diseases in wildlife may have serious consequences for the health of wildlife species, domestic animals, and humans, as these changes affect the ecology of the pathogens, their hosts, and their environment (Daszak et al., 2000). Evidence that infectious pathogens play a role in the population dynamics of wildlife is mounting (Frick et al., 2010; Thompson et al., 2010), and diseases are increasingly recognized as causes of marked declines or even local extinctions of wildlife species (Oaks et al., 2004; Frick et al., 2010).

The fact that diseases have been shown to affect the population dynamics of wildlife is a significant conservation concern (Daszak et al., 2001; Frick et al., 2010). In many cases, little is understood about the ecology of these diseases, in part because of the challenges inherent in identifying parameters of wildlife populations, measuring exposure to and infection with pathogens, and accurately assessing mortality in wildlife (Wobeser, 2006), and additionally because of the lack of infrastructure present to conduct wildlife disease surveillance and monitoring (Kuiken et al., 2005). Because the effects of an infectious disease on a population may depend on a variety of factors (Wobeser, 2006), information about pathogen transmission dynamics and virulence, host population dynamics, and environmental variables may all be used to help determine the role of a disease in the population dynamics of the host. Knowledge of the infectious diseases present in these populations is essential to the development of effective conservation goals and management strategies for wildlife.

In the Arctic, host and pathogen diversity is relatively low, which may increase the sensitivity of Arctic ecosystems to environmental change and invasions of new biota (Davidson et al., 2011). Increasing anthropogenic influences such as resource exploration and extraction, climate change, introduction of domestic and invasive animal species, environmental contaminants, and tourism have the potential to alter these fragile ecosystems and affect the health of Arctic species (Kutz et al., 2009). For example, responses to environmental changes by seabird populations can vary from subtle and sublethal effects to massive die-offs (Mallory et al., 2010a). By collecting baseline data and monitoring health and disease in Arctic wildlife species, we can gain a greater understanding of the effects of ecological changes and thus better equip wildlife managers to evaluate and implement management efforts if necessary (Kutz et al., 2009).

Avian cholera, a bacterial disease caused by Pasteurella multocida, is a significant cause of mortality in numerous waterfowl species (Samuel et al., 2007). Infection can result in acute death, killing birds so rapidly that they may be found with crops full of food or still sitting on their clutch (Samuel et al., 2007). Avian cholera outbreaks in waterfowl are often detected when large aggregations of birds have gathered, for example, at stopover sites and breeding colonies (Blanchong et al., 2006). These outbreaks can result in rapid and large-scale mortality in multiple avian species (Samuel et al., 2007).

Despite the substantial amount of research conducted on avian cholera in wild waterfowl, the factors that precipitate outbreaks remain unclear. Two hypotheses have been proposed to explain the recurrent pattern of avian cholera outbreaks in specific geographical locations. The first is that $P$. multocida may persist within the soil, water, or other environmental elements in wetlands, which act as a disease reservoir that can initiate outbreaks in susceptible birds. The second is that apparently healthy birds of one or more waterfowl species can act as carriers of the bacteria and shed P. multocida in oral or nasal secretions or feces, which can result in disease outbreaks in groups of more susceptible individuals of their own or other waterfowl species (Samuel et al., 2005). To date, there is evidence that lesser snow geese (Chen caerulescens caerulescens) and possibly other waterfowl species may serve as disease reservoirs and shed $P$. multocida into the environment (Samuel et al., 2005), but further investigations into the persistence of bacteria in the environment and the prevalence of carrier birds are still needed.

Avian cholera has caused annual large-scale mortality at the largest northern breeding colony of the common eider (Somateria mollissima borealis) in Canada (East Bay Island, Nunavut), since it was first detected there in 2005 (Fig. 1). Adult eider survival rates and reproductive success on East Bay Island have plummeted since the first confirmed avian cholera outbreak, and the number of breeding pairs is now at the lowest since population surveys began in 2001 (Buttler, 2009; Descamps et al., 2009). Intriguingly, 


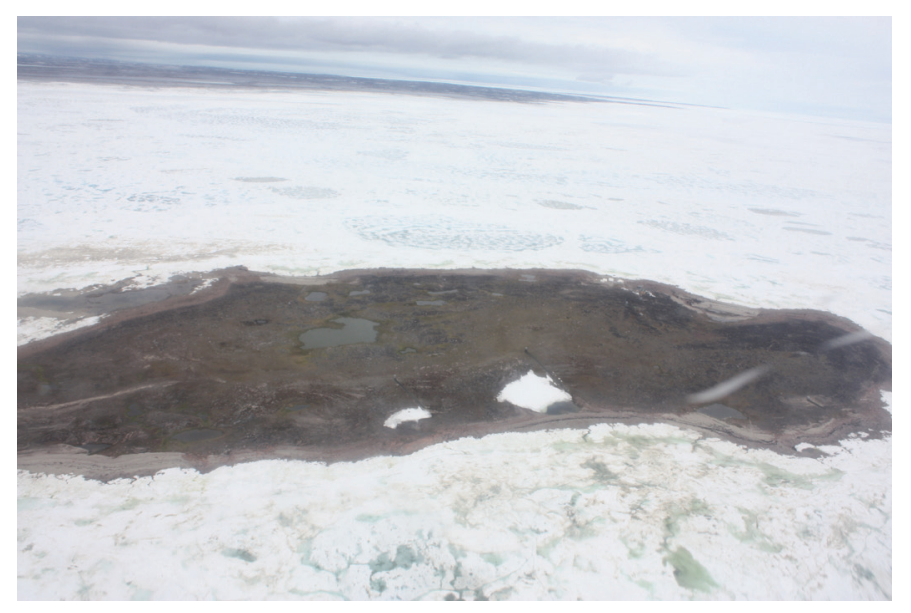

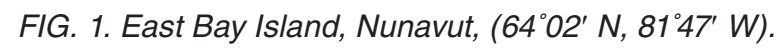

interviews with Inuit residents from communities near to the affected colonies in Nunavut revealed that large die-offs of eiders due to infectious disease had never before been seen during the respondents' lifetimes (Henri et al., 2010). Outbreaks of avian cholera had also been detected in several common eider colonies in northern Quebec in 2004 and 2006 (Gaston, 2004; M. Simard and Canadian Cooperative Wildlife Health Centre, unpubl. data).

Northern common eiders are a large, long-lived sea duck with relatively low recruitment and rate of reproduction (Merkel, 2004). Common eiders return to the same nesting colony in successive breeding seasons (Mallory et al., 2010b) and breed in the eastern Canadian Arctic and in Greenland. Northern common eiders breeding in northern Canada overwinter in eastern Atlantic Canada and on the southwest coast of Greenland (Mosbech et al., 2006). In northern Canada and western Greenland, common eiders are an important part of subsistence harvests in some communities, and sport hunters also hunt them in their eastern wintering sites (Gilliland et al., 2009). Undoubtedly, eiders are an integral component of northern ecosystems and one of the most heavily harvested birds in the Arctic (Gilliland et al., 2009). During the latter part of the 20th century, eider populations in Greenland and parts of the Canadian Arctic demonstrated declines, which were due in part to harvesting levels (Robertson and Gilchrist, 1998; Merkel, 2004; Gilliland et al., 2009; Merkel, 2010). Currently, these populations do appear to be recovering (Chaulk et al., 2005; Merkel, 2010), but monitoring of eider populations continues in both countries because other factors, such as climate change and disease, will continue to affect eider population dynamics.

Very little is known about the ecology of avian cholera in common eiders in northern Canada. In addition to the high rates of female common eider mortality (Buttler, 2009), research has shown that avian cholera outbreaks have a negative effect on reproduction and duckling survival (Descamps et al., 2009, 2011). The recent emergence of avian cholera in the eastern Arctic provides a unique opportunity to investigate the impacts of an infectious disease on wildlife populations.
Rapid environmental changes, together with increasing anthropogenic pressure on wildlife populations and their habitats in the Arctic, provide an impetus to examine factors that cause changes in wildlife populations (Mallory et al., 2010b). Through my $\mathrm{PhD}$ research project, I will examine several hypotheses related to disease reservoirs and host-pathogen transmission dynamics, while addressing gaps in current understanding of the disease dynamics of avian cholera in northern Canada.

\section{OBJECTIVES AND METHODS}

The main objective of my research is to evaluate hypotheses about avian cholera reservoirs and origins and the ecology of the disease in common eider populations in the eastern Canadian Arctic. Additionally, because avian cholera is a disease of migratory birds, I am interested in determining the geographic and temporal scope of avian cholera in the North and in mapping potential movements of the pathogen, both within eider breeding and wintering locations and in other potential carrier species. My specific objectives are 1) to investigate whether common eiders or other sympatric avian species (e.g., lesser snow geese) are carriers of Pasteurella multocida and therefore a source of the organism for annual avian cholera outbreaks in the Arctic, 2) to investigate whether the Arctic environment is a source of $P$. multocida for initiating or perpetuating avian cholera outbreaks (or both), 3) to determine the spatial and temporal distribution of $P$. multocida in Canada's eastern Arctic, 4) to investigate the ultimate origins of the bacteria causing recent outbreaks in northern Canada, 5) to examine the impact of $P$. multocida carrier status and avian cholera on common eider survival and reproduction, and 6) to examine the effect of stress on survival and reproductive success in the face of avian cholera outbreaks.

To address these objectives, this project is divided into three main components. The first involves investigating the geographic and temporal distribution of avian cholera in the eastern Arctic, while examining the host range, origins, and movement of P. multocida throughout the North. Fieldwork and sample collection for this project have been ongoing since 2005. Common eider colony surveys have been conducted in 2010 and 2011 in a number of breeding sites throughout the eastern Canadian Arctic in collaboration with researchers from Carleton University, Environment Canada, and Makivik Corporation, as well as members of the communities of Cape Dorset, Coral Harbour, Kangiqsujuaq, and Aupaluk. The majority of samples, however, have been collected on East Bay Island, where my colleagues have been banding more than 500 eiders prior to the beginning of the breeding season each year since 1996, and then following the birds through the breeding season to gather data on their survival, reproduction, and physiology. Samples from lesser snow geese have been collected in conjunction with annual Arctic goose banding operations and during community-based harvesting on Southampton 
Island, near Cape Dorset on Baffin Island, in the Queen Maud Gulf Migratory Bird Sanctuary, and on the Great Plain of the Koukdjuak. To augment the collection of samples from Nunavut, I hope to collect samples from eiders in Greenland and the eastern Atlantic coast in order to investigate the presence of $P$. multocida in eiders on their wintering sites. In addition to collecting and examining samples from live birds, I have also been working with other pathologists at the Canadian Cooperative Wildlife Health Centre to examine bird carcasses found on colonies or collected by biologists or local residents and determine the cause of death. As part of the surveillance for avian cholera in the North, we also attempt to isolate $P$. multocida from any birds that have died of the disease.

The second component of the project is investigating the presence and distribution of carrier birds (common eiders, snow geese, or both) and the role of environmental reservoirs in initiating and perpetuating avian cholera outbreaks. Samples collected from apparently healthy birds (live or hunted) and the environment are being screened for $P$. multocida, using a polymerase chain reaction assay (PCR) (Corney et al., 2007), to determine whether carrier birds or the environment acts as a reservoir for avian cholera outbreaks. All PCR-positive samples will be cultured to conduct genotyping studies that explore the relatedness among P. multocida strains collected from different species, years, and locations. These results will shed light on the origins and movement of the bacterial strains causing disease in northern birds, as well as identifying important reservoirs of $P$. multocida in the Arctic.

For the final component of this study, I plan to examine the implications of avian cholera outbreaks for common eiders by exploring the relationships among measures of health and infection status in individual eiders. On East Bay Island, weight and morphometric measurements, blood, and feathers are also being collected from eiders that are captured for banding and avian cholera sample collection (oral and cloacal swabs). These samples provide information on body condition, immune function, and stress (feather corticosterone) in individual eiders (Fig. 2). Since eiders are followed throughout the breeding season, data are also collected on reproductive success and survival. The relationships between these factors and P. multocida carrier status will provide information on additional risk factors that may make eiders more susceptible to mortality or reduced reproductive success during avian cholera outbreaks.

Since I began my PhD research in 2010, I have had the privilege of participating in several extended fieldwork trips and have begun developing and running laboratory assays to test the samples that have been collected. To date, samples have been collected from more than 6000 birds in the eastern Arctic since 2005. In addition, more than 1500 environmental samples have been collected from freshwater ponds on East Bay Island and other field locations in the eastern Arctic. Preliminary results of the PCR screening indicate between $3 \%$ and $6 \%$ of apparently healthy common eiders on East Bay Island carry some strain of

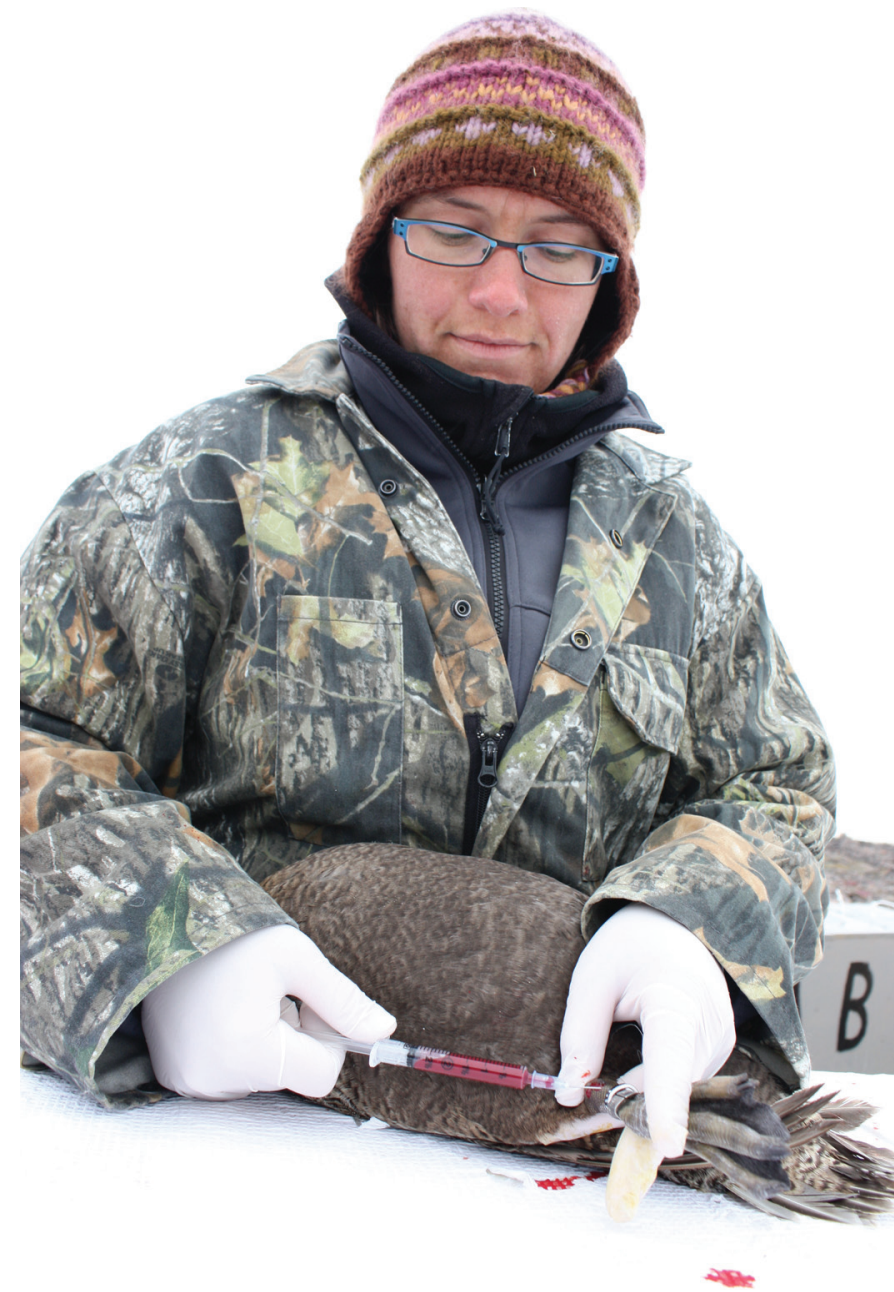

FIG. 2. Jane Harms collecting a blood sample from a female common eider.

P. multocida, suggesting that birds are potential carriers of P. multocida. However, further bacterial characterization is required to determine whether the strains from carrier birds are similar to those initiating outbreaks.

\section{SIGNIFICANCE}

There is little doubt that Arctic ecosystems are undergoing important ecological changes, which include a rapidly changing climate (Kutz et al., 2009) and increasing development pressure (Mallory et al., 2010a). These changes have the potential to alter ecosystem balances and may facilitate the emergence and movement of diseases in wildlife. Investigating and understanding wildlife disease in the North presents many challenges; novel approaches to sample collection and analysis are needed, as well as continuous collaboration and information exchange among wildlife managers, biologists, community members, and scientists.

Avian cholera in the North presents an opportunity for collaborative study of the emergence of an infectious disease in a wildlife species that is an integral part of the 
northern ecosystem and an important component of the subsistence harvest. This research will provide new information about reservoirs of avian cholera in northern ecosystems and about the movement of wildlife pathogens in the North. I hope that this work will improve our understanding of the effects of disease on wildlife populations and individuals and the factors that regulate eider population dynamics. Understanding these effects is imperative not only for conservation concerns, but also because common eiders are an important source of food, eggs, and down for subsistence hunters in Nunavut and Greenland (Henri et al., 2010), and large-scale mortality of eiders will be detrimental to sources of food and income for northern residents. Ultimately, this research will be used to support conservation decisions involving control and management of disease and evaluation of harvest regulations that will ensure sustainable eider populations in Canada.

\section{ACKNOWLEDGEMENTS}

I am most honored to be the recipient of the Arctic Institute of North America's Lorraine Allison Memorial Scholarship. Funding for my research has also been provided by Environment Canada, the Canadian Wildlife Service, the Western College of Veterinary Medicine (Interprovincial Graduate Student Fellowship and the Wildlife Health Research Fund), Ducks Unlimited's Institute for Waterfowl and Wetland Research, the Nunavut Wildlife Research Trust, the Natural Sciences and Engineering Research Council of Canada, Strategic Applications of Genomics in the Environment, Indian and Northern Affairs Canada (Northern Scientific Training Program), and the University of Saskatchewan. I am deeply grateful for the guidance, encouragement, and support from my supervisor, Dr. Catherine Soos, and thankful for the guidance from other committee members Dr. Frederick Leighton, Dr. Janet Hill, Dr. Grant Gilchrist, and Dr. Beverly Kidney, and for the support of my department. I am indebted to the students and field crew members who have assisted me in the field with sample collection, in the laboratory, and in designing portions of this research. I thank Dr. Jeff Foster and Christina Allen for essential guidance regarding sample testing and analysis. I am also grateful to the Environment Canada collaborators who have graciously collected samples for this project and to the community members in the North who have participated in many aspects of this program.

\section{REFERENCES}

Blanchong, J.A., Samuel, M.D., and Mack, G. 2006a. Multispecies patterns of avian cholera mortality in Nebraska's Rainwater Basin. Journal of Wildlife Diseases 42(1):81 -91.

Buttler, E.I. 2009. Avian cholera among Arctic breeding common eiders Somateria mollissima: Temporal dynamics and the role of handling stress in reproduction and survival. MSc thesis, Carleton University, Ottawa, Ontario. 84 p.
Chaulk, K., Robertson, G.J., Collins, B.T., Montevecchi, W.A., and Turner, B. 2005. Evidence of recent population increases in common eiders breeding in Labrador. Journal of Wildlife Management 69(2):805-809.

Corney, B.G., Diallo, I.S., Wright, L.L., Hewitson, G.R., De Jong, A.J., Burrell, P.C., Duffy, P.F., et al. 2007. Pasteurella multocida detection by 5' Taq nuclease assay: A new tool for use in diagnosing fowl cholera. Journal of Microbiological Methods 69(2):376-380.

Daszak, P., Cunningham, A.A., and Hyatt, A.D. 2000. Emerging infectious diseases of wildlife-Threats to biodiversity and human health. Science 287:443-449.

2001. Anthropogenic environmental change and the emergence of infectious diseases in wildlife. Acta Tropica 78(2):103-116.

Davidson, R., Simard, M., Kutz, S.J., Kapel, C.M.O., Hamnes, I.S., and Robertson, L.J. 2011. Arctic parasitology: Why should we care? Trends in Parasitology 27(6):238-244.

Descamps, S., Gilchrist, H.G., Bêty, J., Buttler, E.I., and Forbes, M.R. 2009. Costs of reproduction in a long-lived bird: Large clutch size is associated with low survival in the presence of a highly virulent disease. Biology Letters 5(2):278-281.

Descamps, S., Forbes, M.R., Gilchrist, H.G., Love, O.P., and Bêty, J. 2011. Avian cholera, post-hatching survival and selection on hatch characteristics in a long-lived bird, the common eider (Somateria mollissima). Journal of Avian Biology 42:39-48.

Epstein, P.R. 2002. Biodiversity, climate change, and emerging infectious diseases. In: Aguirre, A.A., Ostfeld, R.S., Tabor, G.M., House, C., and Pearl, M.C., eds. Conservation medicine: Ecological health in practice. Oxford: Oxford University Press. 27-39.

Frick, W.F., Pollock, J.F., Hicks, A.C., Langwig, K.E., Reynolds, D.S., Turner, G.G., Butchkoski, C.M., and Kunz, T.H. 2010. An emerging disease causes regional population collapse of a common North American bat species. Science 329:679-682.

Gaston, A.J. 2004. Report on surveys and research at Digges Island and vicinity, 27 July - 9 August 2004. Ottawa: Canadian Wildlife Service. 15 p.

Gilliland, S.G., Gilchrist, H.G., Rockwell, R.F., Robertson, G.J., Savard, J.-P.L., Merkel, F., and Mosbech, A. 2009. Evaluating the sustainability of harvest among northern common eiders Somateria mollissima borealis in Greenland and Canada. Wildlife Biology 15(1):24-36.

Henri, D., Gilchrist, H.G., and Peacock, E. 2010. Understanding and managing wildlife in Hudson Bay under a changing climate: Some recent contributions from Inuit and Cree ecological knowledge. In: Ferguson, S.H., Loseto, L.L., and Mallory, M.L., eds. A little less Arctic: Top predators in the world's largest northern inland sea, Hudson Bay. Dordrecht, The Netherlands: Springer. 267-289.

Kuiken, T., Leighton, F.A., Fouchier, R.A.M., LeDuc, J.W., Peiris, J.S.M., Schudel, A., Stöhr, K., and Osterhaus, A.D.M.E. 2005. Pathogen surveillance in animals. Science 309:1680-1681.

Kutz, S.J., Jenkins, E.J., Veitch, A.M., Ducrocq, J., Polley, L., Elkin, B., and Lair, S. 2009. The Arctic as a model for anticipating, preventing, and mitigating climate change impacts 
on host-parasite interactions. Veterinary Parasitology 163(3): $217-228$.

Mallory, M.L., Robinson, S.A., Hebert, C.E., and Forbes, M.R. 2010a. Seabirds as indicators of aquatic ecosystem conditions: A case for gathering multiple proxies of seabird health. Marine Pollution Bulletin 60(1):7-12.

Mallory, M.L., Loseto, L.L., and Ferguson, S.H. 2010b. The future of Hudson Bay: New directions and research needs. In: Ferguson, S.H., Loseto, L.L., and Mallory, M.L., eds. A little less Arctic: Top predators in the world's largest northern inland sea, Hudson Bay. Dordrecht, The Netherlands: Springer. $291-303$.

Merkel, F.R. 2004. Evidence of population decline in common eiders breeding in Western Greenland. Arctic 57(1):27-36.

. 2010. Evidence of recent population recovery in common eiders breeding in Western Greenland. Journal of Wildlife Management 74(8):1869-1874.

Mosbech, A., Gilchrist, G., Merkel, F., Sonne, C., Flagstad, A., and Nyegaard, H. 2006. Year-round movements of northern common eiders Somateria mollissima borealis breeding in Arctic Canada and West Greenland followed by satellite telemetry. Ardea 94(3):651-665.

Oaks, J.L., Gilbert, M., Virani, M.Z., Watson, R.T., Meteyer, C.U., Rideout, B.A., Shivaprasad, H.L., et al. 2004. Diclofenac residues as the cause of vulture population decline in Pakistan. Nature 427:630-633.

Robertson, G.J., and Gilchrist, H.G. 1998. Evidence of population declines among common eiders breeding in the Belcher Islands, Northwest Territories. Arctic 51(4):378-385.

Samuel, M.D., Shadduck, D.J., Goldberg, D.R., and Johnson, W.P. 2005. Avian cholera in waterfowl: The role of lesser snow and Ross's geese as disease carriers in the Playa Lakes region. Journal of Wildlife Diseases 41(1):48-57.

Samuel, M.D., Botzler, R.G., and Wobeser, G.A. 2007. Avian cholera. In: Thomas, N.J., Hunter, D.B., and Atkinson, C.T., eds. Infectious diseases of wild birds. Ames, Iowa: Blackwell Publishing Ltd. 239-269.

Thompson, R.C.A., Lymbery, A.J., and Smith, A. 2010. Parasites, emerging disease and wildlife conservation. International Journal for Parasitology 40(10):1163-1170.

Wobeser, G.A. 2006. Essentials of disease in wild animals. Ames, Iowa: Blackwell Publishing Ltd. 243 p.

N. Jane Harms, a doctoral candidate in the Department of Veterinary Pathology, Western College of Veterinary Medicine, University of Saskatchewan, is the 2011 recipient of the Lorraine Allison Memorial Scholarship.naomi.harms@usask.ca 